\title{
EVALUACIÓN DE ALTERNATIVAS DE MANEJO DE POSCOSECHA EN HORTALIZAS DE HOJA SOBRE LAS PÉRDIDAS A NIVEL MINORISTA
}

\author{
Ortiz Mackinson, M. ${ }^{1}$; Rotondo, R. ${ }^{1}$; Grasso, R. ${ }^{1}$; CALANI, P. ${ }^{1 ;}$ \\ Mondino, C..$^{1-3 ;}$ FIRPO I. ${ }^{1} \&$ Cosolito P. ${ }^{2}$
}

\section{RESUMEN}

Las hortalizas de hoja presentan pérdidas elevadas desde la producción primaria hasta el consumidor. El objetivo fue evaluar las pérdidas poscosecha en acelga, cebolla de verdeo, puerro, rúcula, radicheta y espinaca. Se evaluó diariamente el efecto del ambiente de almacenamiento (con o sin cámara frigorífica) la hidratación (con o sin inmersión en agua clorinada) y material de sujeción de los manojos (cinta o Stipa, sp), durante la distribución minorista, en época estival (19 al 26 de febrero de 2013). Variables medidas: pérdida de peso por descarte, pérdida o ganancia de peso por agua y pérdidas totales, en porcentaje. La unidad experimental fue el manojo, con cuatro repeticiones por tratamiento. Se aplicó un modelo de medidas repetidas en el tiempo con procedimiento MIXED de SAS. En cámara frigorífica, disminuyeron las pérdidas poscosecha, debido al menor descarte y pérdida de agua, para todas las especies evaluadas, incrementando significativamente el período de almacenamiento. En los tratamientos con y sin hidratación en el ambiente refrigerado el descarte fue similar en todas las especies evaluadas; mientras que en el no refrigerado aumentó las pérdidas en acelga y cebolla de verdeo. Las pérdidas de peso por agua se redujeron en acelga, radicheta y rúcula en ambiente no refrigerado; y en puerro y cebolla de verdeo en ambos ambientes. La sujeción de los manojos con cinta redujo la pérdida de peso por agua en rúcula almacenada en cámara y en radicheta y puerro en el no refrigerado.

Palabras claves: cámara frigorífica, calidad, hidratación.

1.- Cátedra de Cultivos Intensivos. Horticultura. Facultad de Ciencias Agrarias (UNR). C.C. 14 (S2125ZAA) Zavalla, provincia de Santa Fe. Email: ortizmackinson@hotmail.com

2.- Cátedra de Estadística. FCA (UNR).

3.- AER-INTA Arroyo Seco.

Manuscrito recibido el 24 de febrero de 2014 y aceptado para su publicación el 15 de mayo de 2014. 
M. Ortiz Mackinson et al.

\section{SUMMARY}

Evaluation of alternatives of leafy vegetables postharvest handling on the losses at the retail level Leafy vegetables present high losses from the growing stage until they reach the consumer. The objective of this work was to evaluate post-harvest losses of Swiss chard, green onions, leeks, radish, rocket and spinach, at the retail marketing stage. Daily measurements were taken in the summer (19th to 26th February 2013) to evaluate the effects of storage environment (with and without cold storage); hydration treatment (with and without immersion in chlorinated water), and materials used for holding bunches (tape or Stipa sp) on the following variables: weight loss due to discarding, loss or gain of weight due to water lost or absorbed, and percentage of total losses. The experimental unit was a bunch with four replicates per treatment. Statistical analysis was performed with a model of repeated measurements over time with MIXED procedure of SAS. Cold storage reduced losses by discard and water loss, and significantly extended the storage life of all species tested. In cold room storage, losses by discard were similar in treatments with or without hydration, for all species. However, loss by discard increased in both hydrated and non-hydrated Swiss chard and green onions bunches not kept in a cold storage room. Loss of weight by water decreased in Swiss chard, radish and rocket not kept in cold storage, and in leeks and green onions stored in both environments. Holding bunches with tape reduced loss of weight by water in rocket bunches in cold room storage, and in radish and leeks not kept in cold storage.

Key words: cold storage room, quality, hydration.

\section{INTRODUCCIÓN}

Las hortalizas están sujetas a la misma problemática de pérdidas que ocurre en la producción mundial de alimentos destinada al consumo humano, desde la producción primaria hasta el consumidor, estimadas globalmente en un $30 \%$ (Gustavsson et al., 2011). Existe escasa información adecuada para establecer acciones que permitan mejorar la competitividad del sector (Mondino et al., 2007). Esto se debe a la dificultad para evaluar las pérdidas en numerosas especies y la ausencia de métodos universales para su medición (Decoene, 2001). En países en desarrollo las pérdidas son cuantiosas variando en productos frescos entre el 25 al $50 \%$ de la producción (Kader, 2007).
Las hortalizas de hoja poseen como principal componente el agua, pudiendo llegar hasta un $95 \%$ de su peso total (Wills et al., 1999). La pérdida de agua es una causa principal del deterioro porque provoca pérdidas cuantitativas directas, traducidas en pérdidas de peso comercializables. También provoca pérdidas en la apariencia, manifestada a través de la marchitez y arrugamiento del producto, en la calidad textural, percibida como ablandamiento, flacidez, disminución de crujencia, jugosidad y calidad nutricional (Kader, 2007). Las hortalizas poseen una alta perecibilidad debido a sus relativamente elevadas tasas transpiratoria y respiratoria, como así también la susceptibilidad a las alteraciones físicas que pueden producir pérdidas directas, daños y una

42 | Revista FAVE - Ciencias Agrarias 13 (1 - 2) 2014 